\title{
Industrialization Strategy and Industrial Relations Policy in Malaysia
}

\author{
Sarosb Kuruvilla
}

he notion that the logic of industrialism (Kerr et al. 1960) would lead to a convergence of industrial relations systems has been swept aside by history. Nonetheless, in addition to political regimes and market pressures, industrialization is still regarded as a central variable in explaining industrial relations policies or transformations in industrial relations systems. The argument that stages or levels of industrialization are correlated with certain patterns of industrial relations and trade union influence has received particular attention. For instance, Frenkel (ed., 1993) suggests that, in the most general terms, it appears that a country's level of industrialization is related to the influence trade unions have in shaping workplace industrialization. In Frenkel's nine-country study, the least industrialized countries-Malaysia, Thailand, and China-show less trade union influence in workplace industrial relations than the more developed countries, such as Singapore. Frenkel contends, however, that it is simplistic to assume that industrial relations systems in countries at similar levels of industrialization ought to be similar, given the variation in patterns of industrialization across the four "Asian tigers," which are at similar levels of industrialization.

M. Bjorkman, L. Lauridsen, and H. Marcussen (1988) hypothesize that different patterns of industrialization are associated with different kinds of capital-labor relations. Their theoretical work suggests little or no relationship between capital-labor relations and two levels of import-substitution industrialization (simple and advanced). They argue that simple exportoriented industrialization, based on labor-intensive production, is associ-

My thanks to Pan Shih-Wei and Lee Byoung-Hoon for assistance with the research and to Stephen Frenkel and Jeffrey Harrod for their helpful comments. Errors, if any, are mine. 
ated with a highly repressive labor system, while more advanced forms of export-oriented industrialization, based on capital-intensive production systems and that rely on highly skilled labor, are likely to result in more inclusive and less repressive industrial relations systems. In their scheme, different forms of industrialization reflect the nature of different forms of capital accumulation, which translate into different kinds of capital-labor relations, an argument Sharma (1985) also advanced. ${ }^{1}$ Empirical tests of their propositions have yet to be conducted, however. Deyo (1989) also finds policies of labor suppression by East Asian states consequent to export-oriented industrialization. ${ }^{2}$

Somewhat related to this argument is the suggestion of the new international division of labor (NIDL) theorists that industrialization has been thrust upon peripheral societies by core economic powers and that this industrialization, through the transmission belt of global multinationals and condoning local governments, has led to union repression and marginalization in peripheral societies. Frenkel (ed., 1993) does not find this hypothesis to be supported in his study, although he suggests that further research is necessary in this regard.

What is missing from this literature is a closely reasoned argument about how industrialization strategies affect the actions of management, labor, and government in the labor relations sphere. More specifically, what factors lead governments to decide on a specific industrialization strategy? What implications does the choice of such a strategy have for the industrial relations (IR) system and, specifically, the institutional arrangements governing labor relations? The institutional arrangements in particular are central to the way in which the industrial relations policies of the state and the industrial relations practices of the actors develop and change. A focus on rules and laws is not enough. Previous literature has, by and large, ignored these arrangements. Instead, they have concentrated on broader typologies of IR systems, such as "collaborative-repressive."

In this chapter, a different view is taken of the relationship between industrialization strategies and industrial relations policy and practice. I argue that it is not the logic of industrialism or the levels of industrialization per se but the choice of an industrialization strategy and the shifts between such strategies that influence changes in industrial relations policies. Different industrialization strategies exist, such as import-substitution, export-oriented, basic industries, and small-scale strategies, each with its attendant implications for industrial relations policies. The argument developed here is that it is the shift from one strategy to another that is important in understanding transformations in industrial relations systems (i.e., these shifts provide a window through which to assess the dynamics of change in industrial relations systems).

It is not my intent to suggest that the changes in industrial relations policies are solely determined by shifts in the industrialization strategy. 
Other factors, such as changes in political regimes, are often critical reasons industrial relations systems change, as demonstrated by Collier and Collier (1991) for Latin America and suggested by various others (e.g., Frenkel, ed., 1993; Bjorkman, Lauridsen, and Marcussen 1988). It is important to note, however, that the relative importance of various factors differs from country to country. In the countries of East Asia and Southeast Asia, whose industrialization experiences are relatively recent and largely successful and whose political regimes, with the exception of Thailand, have been relatively stable, the variables related to industrialization may have stronger explanatory power than those related to politics.

Nor do I argue that the type of industrialization strategy that a country pursues is deterministic (i.e., a change from strategy $X$ will lead to industrial relations systems type $Y$ ). Rather, I argue that the shift from one strategy to another provides a rare "moment in the transition" of economies that enables researchers to view the dynamics of industrial relations transformation. The particular pressures and the direction of change in an IR system are necessarily specific to each country, but in the context of the NICs of Southeast Asia, the shifts in industrialization strategies could provide a general framework for the analysis of IR system change. Implicit in this argument is the notion that certain industrialization strategies tend to be associated with, and to sustain, certain industrial relations policies and practices.

In this chapter, Malaysia is used as an example to examine this "moment in transition" in an industrial relations system. In Malaysia, industrialization strategies were largely a function of the ethnic tensions and the economic results of policies introduced to manage these tensions. I argue that the shift from an import-substitution policy to an exportoriented policy resulted in an increasingly inflexible and governmentdominated industrial relations system. In assessing the dynamics of change in the industrial relations system, three factors appear important. These include the demands of the industrialization strategy itself (EOI, based on low-cost, labor-intensive manufacturing), the state's dependence on foreign investment to sustain this strategy, and the state's need to increase the economic efficiency of state-run plants, all of which constituted pressures for change in industrial relations.

Although the focus is on Malaysia, the argument is equally applicable to the Philippines, Indonesia, and Thailand (Kuruvilla 1992), as well as to other Third World countries that are under pressure to restructure their economies (Katz, Kuruvilla, and Turner forthcoming; Singh 1992). The next section briefly describes the Malaysian economy, including previous and current state industrialization strategies. I then discuss industrial relations strategies. This is followed by an analysis of the outcomes of Malaysia's industrial relations policy. The final section provides some concluding observations and notes several implications for further research. 


\section{Malaysia's Economy Today}

Malaysia is one of the fastest growing economies in the world and in many ways a Third World success story. Twenty years of sustained growth and diversification have reduced the economy's reliance on primary products, such as tin and rubber. Malaysia is still the world's largest exporter of tin and rubber, however, the largest exporter of palm oil, and a significant producer of oil, natural gas, and timber. More recently, it has become one of the largest manufacturers of semiconductors and a sizable manufacturer of electronics, electrical products, and textiles. Exports account for about 61 percent of gross national product (GNP), which makes the economy very dependent on the external economic climate.

Although growth was slowed during 1982 and 1985-86 as a result of falling prices in commodities, Malaysia has sustained high economic growth since then through its booming export trade in manufacturing, which is driven primarily by foreign investment. Industry has supplanted agriculture as the major contributor to gross domestic product, accounting for 42 percent of GDP, and low-cost, labor-intensive manufacturing accounts for about 48 percent of export earnings. In the last few years, Malaysia's GDP has grown at an average annual rate of 8.7 percent, making it among the highest in the world, and manufacturing has grown at about 15 percent annually. National and per capita incomes are increasing at a rate of 7 percent annually, and the per capita income-about U.S. $\$ 2,000$-is higher than the per capita incomes of most Third World countries.

Foreign investment in Malaysia continues to increase, attracted by the favorable investment policies, the cheap, docile, and skilled labor, and the well-developed infrastructure (Malaysia has 30,000 kilometers of paved roads, reliable and efficient telecommunications, cheap and abundant electricity, and efficient transportation systems). Foreign investment is still dominated by low-cost, labor-intensive industries, although a small shift to more higher-technology production is apparent and the country has begun attracting more larger companies. Japan is the largest investor, closely followed by Taiwan, which alone accounts for 25 percent of the total foreign direct investment and the largest number of projects. Industrial relations in Malaysia have recently been characterized as becoming highly repressive and trade unions as weak, excluded by the government in decision making at national levels, and having very little influence at the workplace level (Arudsothy and Littler 1993). Table 3.1 provides basic economic statistics.

\section{Industrialization Strategy in Malaysia}

Malaysia's industrialization strategy has been determined largely by tensions between the three dominant ethnic groups: the Malays, who form 
Table 3.1. Summary of the Malaysian Economy, 1990

\begin{tabular}{lc}
\hline Population (in millions) & 16.92 \\
Per capita income (in U.S.\$) & 2,000 \\
Civilian employment & \\
$\quad$ Agriculture & $30.8 \%$ \\
$\quad$ Industry & $23.1 \%$ \\
$\quad$ Services & $43.6 \%$ \\
Sectoral share of GDP & \\
$\quad$ Manufacturing & $41.7 \%$ \\
Agriculture & $19.4 \%$ \\
Services & $38.9 \%$ \\
Unemployment rate & $8.1 \%$ \\
Unionization rate & $10.1 \%$ \\
Exports as percentage of GDP & 61 \\
Share of labor-intensive sector involved in producing & \\
manufactured goods for export & \\
1980 & $29 \%$ \\
1988 & $51 \%$ \\
Contribution of EPZs to total exports & \\
1988 & $33 \%$ \\
Contribution of MNCs to total exports & \\
1971 & $28 \%$ \\
1980 & $54 \%$ \\
1986 & $58 \%$ \\
\hline
\end{tabular}

Sources: Lim and Pang Eng Fong 1991; Ministry of Finance 1991; author's calculations.

54 percent of the population, and the Chinese and Indians, who represent 37 and 16 percent respectively (Bowie 1991). The following discussion draws heavily on A. Bowie's analysis.

Before its independence from Great Britain in 1957, Malaysia was dependent on exports of primary commodities, and tin and rubber production accounted for 85 percent of export earnings and 48 percent of GDP. Agriculture, mining, banking, and external trade were controlled by foreign interests (mostly British), while small-scale industry was owned largely by ethnic Chinese and Indians. ${ }^{3}$ Ethnic Malays were concentrated largely in the rural agricultural sectors. Although they accounted for 50 percent of the population, they owned less than 10 percent of the registered businesses and less than 1.5 percent of the share capital and paid less than 4 percent of the nation's income tax. At independence, the industrial strategy relied primarily on the processing of raw materials for export.

\section{Import-Substitution Industrialization}

Market-Led ISI. Economic policy in 1957-70 focused on the state's involvement in the development of an infrastructure and the rural sector 
(which accounted for 30 percent of planned expenditures), while industrialization was left to the private sector. The state restricted itself to the creation of a favorable climate to attract foreign investment in importsubstitution industries. Among the state initiatives during this period was the enactment of the Pioneer Industries Relief from Income Tax Ordinance of 1958 and the creation of the Malaysian Industrial Development Finance Corporation, which was responsible for providing investment capital and for the development of industrial estates. After the 1968 withdrawal of Singapore from the Federation of Malaya, the Investment Incentives Act was introduced, aimed at stimulating industrial growth by attracting foreign investment with a plethora of tax concessions, enhancing the Pioneer status conditions, and creating free trade zones. (For a detailed description of specific policies, see Spinanger 1986.)

The decision to leave industrial investment to the private sector was largely a political compromise reached between the parties making up the ruling alliance (Bowie 1991). The United Malay National Organization (UMNO) realized that Chinese and Indian acceptance of the UMNO's political role was to some extent dependent on the state's not interfering in private commerce and industry (which they dominated) beyond its regulatory role. The UMNO therefore accepted (temporarily) the Chinese and Indian dominance of business and commerce, in exchange for their acceptance of UMNO political domination and UMNO efforts to increase Malay participation in the rural sector and in transportation, mining, construction, and timber industries. World Bank recommendations favoring industrialization under private sector auspices also influenced this policy (Spinanger 1986; Bowie 1991).

The strategy had mixed results. On the one hand, by 1969, Malaysia's economy had grown by more than 5 percent per year, manufacturing growth rates were high, at 10.2 percent annually, and private investment had increased by 7.3 percent annually. The fastest growing industries were textiles, electrical machinery, and motor vehicle assembly. On the other hand, the participation of the ethnic Malays in this economic growth was limited. Ownership among Malays still remained static, at 1.5 to 2 percent, while the share among the Chinese and Indians grew somewhat. ${ }^{4}$ Malay participation in manufacturing employment had increased only marginally and was much lower in skilled and managerial jobs.

It became clear that the market-led approach succeeded in strengthening the economic position of the Chinese and Indians, relative to the Malays, and anger over this outcome was responsible for the communal violence after the 1969 parliamentary elections (Bowie 1991; Lim and Pang Eng Fong 1991). The relative economic stagnation of the Malays resulted in Malaysian politics becoming increasingly polarized on ethnic lines during this period (Bowie 1991).

New Economic Policy (NEP) and State-Led ISI. The NEP, promulgated in 
response to Malay nationalism, was designed to increase the ethnic distribution of the work force in proportion to the ethnic distribution of the population and to increase the bbumiputras' ("sons of the soil")-that is, the Malays' - share of corporate ownership from 2.4 percent, in 1970 , to 30 percent by 1990 . The strategy emphasized redistribution via growth in output and employment. In operational terms, employment quotas of 30 percent for Malays were a prerequisite for firms to qualify for import protection and tax concessions. Government contracts were reserved for Malay-owned firms, and all firms had to keep aside 30 percent of their shares for Malays.

Arguing that economic growth would "increase the size of the pie," the UMNO was able to convince its Chinese and Indian counterparts in the ruling alliance that the empowerment of the Malays would not detrimentally affect Chinese and Indian interests. To ensure the levels of growth required, the state, for the first time, became a significant actor in ISI investment. State intervention was justified on the grounds that Malays did not currently possess the wealth or the entrepreneurial ability to start new businesses. The UMNO's investments in the private sector were therefore to be made on behalf of Malay interests and would ultimately pass to Malay hands.

Although these policies resulted in increasing the economic participation of Malays (their share of total manufacturing employment increased to 32 percent, while the percentage of Malays in managerial positions rose to 17 percent and their ownership share to about 8 percent [Bowie 1991]), they were still short of Malay nationalists' expectations. There were not enough qualified Malays to meet the 30 percent employment target in each firm, and the policies did not result in the development of entrepreneurship. Industry continued to be dominated by ethnic Chinese. Bowie (1991) notes an increase in "Ali-Baba"-type ventures in which Malay businessmen acted as "fronts" for Chinese capital.

Citing the failure of the policies to increase the Malays' participation significantly, and under pressure from Malay nationalists, the state intensified its investment in ISI by enacting the Industrial Coordination Act (ICA) of 1976, which gave the Ministry of Trade and Industry complete powers to direct and control the development of industry, including the power to issue licenses to industries based on their compliance with NEP goals. The Bhumiputra Investment Fund was created with state funds for the purpose of investing in shares on behalf of Malays, and the ICA mandated majority share ownership by Malays in all joint ventures and foreign projects. Also during this phase, the Petroleum Development Act of 1976 was enacted, which enabled the government to acquire control over the petroleum and petrochemical industries without compensation (Bowie 1991; Lim and Pang Eng Fong 1991).

The economic implications of state intervention were far-reaching. For 
the first time since independence, the Malaysian state exerted increasing control over the private sector via regulation and direct investment in the furtherance of NEP goals. Government revenues poured into NEP and ICA policies, assuming that private sector investment would continue as before. Private and foreign investment balked at investing, however, given the NEP and ICA policies and fears of nationalization. Consequently, levels of private sector investment fell dramatically, from expected levels of 12 to 14 percent to about 3 percent of GDP in 1976. This shortfall, and the utilization of government funds to buy shares (undersubscribed by the Malay business community for which they were reserved) resulted in a major resource crunch, which led to increased borrowing from international banks. Foreign debt as a percentage of GNP increased from 8.45 percent in 1975 to almost 11 percent by $1976-77$.

\section{Transition to Export-Oriented Industrialization}

The resource crunch drove the government to articulate a mixed policy. On the one hand, the government launched a massive campaign to encourage private and foreign investment during the 1977-80 period. Policies emphasized investment incentives, the development of infrastructural facilities, and numerous tax, labor, and other incentives. (Spinanger 1986 and Lim and Pang Eng Fong 1991 discuss these in greater detail.) Electronics and textile industries were specifically targeted. Foreign companies manufacturing for export were exempted from the ICA policies on Malay share ownership, and labor laws that might have discouraged foreign investment were relaxed or went unenforced. Unions were excluded from key industries and the export sector. This new phase saw the beginnings of massive foreign investment in the electronics sector by U.S. and Japanese companies.

On the other hand, the state increased its involvement in the development of heavy import-substituting industries. The continued failure of state-led NEP and ICA policies to achieve economic power for Malays commensurate with their distribution in the population (Malays owned only 12.4 percent of corporate wealth in 1978 , and the target of 30 percent ownership by 1990 appeared out of reach) led to further pressures from Malay nationalists to increase ownership by Malays (Bowie 1991).

In response, in 1980, Dr. Mahathir Mohammed, the then-industries minister, announced a heavy industries policy (HIP) geared to achieving the twin objectives of accelerating industrial growth and improving the economic position of Malays. Through the Heavy Industries Corporation (HIC), the state now had a leading role in establishing large-scale, capitalintensive, import-substituting industries to provide industrial goods and consumer durables for the domestic market and a foundation to support a range of private sector and consumer goods industries. The HIC invested 
in a series of large-scale joint ventures, including PROTON (Malaysian Small Car Project), iron and steel works at Trengganu, and plants for cement, motorcycles, aluminum, and gas, of which were Japanese private sector firms with about 30 percent investment from the government. ${ }^{5}$

The outpouring of government revenues to sustain the NEP and ICA policies, combined with the recessions of 1982 and 1985 and the draining of revenues by the heavy industries program, drove Malaysia's external debt to unprecedented levels (Lim and Pang Eng Fong 1991). By 1986, debt as a percentage of GNP had tripled, bringing it to 30 percent, over 1976 levels. Foreign borrowing became the primary source of foreign capital inflow in the first half of the 1980s. The poor performance of the HIC contributed further to the revenue crunch. Thus, by 1987, the HIC had reported losses exceeding U.S. $\$ 100$ million, total state liabilities exceeded U.S. $\$ 2.24$ billion, and 37 percent of the public debt was the result of government-backed foreign loans.

Given this second "resource" crunch, and under pressure from the World Bank and other lending agencies, Malaysia announced a series of austerity measures. In addition to cutbacks in public spending, these included the privatization of various state-owned public sector industries. Further, Malay managers in the state-owned heavy industries program were replaced by more "professional" Japanese and private sector managers.

To meet its interest payments on foreign debts, the state also encouraged export-oriented industries, simplifying bureaucratic controls, increasing investment allowances and incentives, and reducing corporate and development taxes. Clearly, the economic situation of the 1980s showed that the state could not reconcile its heavy industries program and its NEP and ICA programs with rapid industrial growth. The state came to be dependent on foreign investment for the growth of its manufacturing sector and exports. As a result, development priorities once again shifted to EOI from a policy of heavy industrialization for an increasingly protected domestic market. Since 1989, favorable external factors, dramatic increases in foreign investment, and growth in exports of manufactured goods have stimulated economic growth.

\section{Outcomes of Export-Oriented Strategy}

The description above suggests that during 1977 and then during 1988 it was the shortage of revenues brought about by the government's involvement in NEP, ICA, and the HIP, and the consequent increases in international debt, that brought about the shift to EOI policies. The shift from an import-substitution strategy to a more export-oriented strategy transformed the Malaysian economy in several ways.

First, foreign direct investment in Malaysia has grown dramatically since 1987. In 1989, total direct foreign investment in Malaysia exceeded 
U.S. $\$ 1.86$ billion, representing a 157 percent increase over the previous year (investment increased by 127 percent between 1987 and 1988) and accounting for roughly 12 percent of GDP. In the first half of 1989, foreign enterprises accounted for 80 percent of the proposed equity investment in the country. Eighty-five percent of these investments were in export-oriented industries.

Second, the origins of investment have changed substantially over the 1980-90 period. Although the United States was the largest investor, its position was rapidly supplanted by Japan and then by the Asian NICs. The majority of these investments are in 100-percent-foreign-owned firms.

Third, the locus of investment (and particularly investment from the NICs) is primarily in the low-cost, labor-intensive, export-oriented manufacturing sector, although recently there has been an increase in the number of small and medium-sized firms from Japan oriented toward more high-skill-based manufacture. Nearly 85 percent of approved manufacturing investors for 1988 were committed to export at least half their production, compared with 25 percent for the $1982-86$ period. The three industries now receiving the largest amount of foreign investment funds are electronics and electrical products, textiles, and chemicals, which export 98 percent of their production.

Fourth, the total manufacturing sector now accounts for 32 percent of employment, 42 percent of GDP, and 40 percent of export earnings. Manufacturing exports have grown by an average of 15 percent annually since 1988 and account for more than half of export earnings. Within this sector, the contribution of low-cost, labor-intensive manufacturers increased from 29 percent of production and export earnings in 1980 to 51 percent in 1988 (Ariff and Hill 1985; Tyers, Phillips, and Findlay 1987). The contribution of export processing zones (characterized by laborintensive production, which contributes to employment creation but little to government revenues) to total exports exceeded 33 percent in 1988 (Ariff and Hill 1985; Tyers, Phillips, and Findlay 1987). Finally, the contribution of transnational corporations to exports has increased from 28 percent of exports in 1971 to 58 percent in 1988 (Tyers, Phillips, and Findlay 1987).

Fifth, the electronics industry has been the centerpiece of this dramatic economic performance. The importance of semiconductors to Malaysia's economy is well known. The electronics industry, specifically manufacturers of semiconductors, employs 16.7 percent of the manufacturing work force (Onn 1989). Total exports of semiconductors exceeded M $\$ 4$ billion, accounting for 24.8 percent of total manufacturing exports in 1989 (Grace 1990). A 1987 United Nations report (United Nations Centre on Transnational Corporations 1987) shows that the majority of foreign (mostly American- and Japanese-owned) plants in the electronics industry 
concentrate on low-skilled assembly and testing, although two higher-skill wafer fabrication plants have been established since 1992 .

In sum, although Malaysia's economic transformation has resulted in impressive growth rates, the EOI strategy has made the country dependent on low-cost, labor-intensive, foreign-dominated manufacturing for export to meet interest payments and sustain industrial growth. The dependence on this form of EOI has forced the Malaysian government to continue to enact policies geared toward attracting and retaining foreign capital to its low-cost export sector. As the next sections will indicate, this transformation has affected labor relations policy significantly.

\section{Government Industrial Relations Policies}

\section{Industrial Relations Policy under ISI: Restricted Pluralism}

This section briefly describes industrial relations policy during the import-substitution period, from the 1950s to about 1977 . The central pieces of legislation in the industrial relations sphere included the Employment Act of 1955, the Trade Unions Ordinance of 1959, and the Industrial Relations Act of 1967. The principle that the government followed was essentially one of pluralism, based on the belief that workers required some degree of fair and humane treatment but also reflecting the view that economic development goals had supremacy over unfettered trade union rights (Bot 1988). The Employment Act focused on legislating fair conditions of work. Although collective bargaining was the primary form for resolving industrial problems, unions were controlled through the union registration process.

Any seven persons could form a union, but the registrar of trade unions had wide discretionary powers in according registration, canceling registration if two or more unions catered to any sector of the work force, or for any other reason and in determining the nature of the bargaining unit. The registrar also had the power to exclude particular individuals from union activity. Although the principle of one union per occupation within an industry should have strengthened the power of unions, P. Arudsothy (1990) suggests that it was used primarily to weed out those unions that were most militant. Unions were allowed to affiliate themselves with peak federations; however, the registrar had the power to withhold permission to do so. In general, the principle followed was that permission to affiliate would be granted if the registrar was convinced that the purpose of affiliation was not for trade union purposes. Peak federations, such as the Malaysian Trade Union Congress (MTUC), were incorporated as societies. This policy was selectively used to ensure that the state exercised control over the growth and character of the labor movement. 
Consistent with the notion of the supremacy of economic development goals, the subjects of collective bargaining were restricted. Unions were not permitted to bargain on issues relating to management decisions with respect to recruitment, promotions, transfers, job assignments, or termination of employment on account of dismissals or retrenchment.

To encourage foreign investment, under the Pioneer Industries ordinance, the state guaranteed that the terms and conditions negotiated with unions were not more favorable than the provisions of the Employment Act of 1955. Strikes were allowed, subject to various restrictions: notice had to be given, a strike ballot had to be taken, and the ballot results had to be registered with the registrar within seven days. The registrar then had ninety days to check the validity of the ballot results. In addition, under the Industrial Relations Act of 1967, strikes were prohibited once the dispute had been referred to arbitration by the minister of labor.

Conciliation was invariably the first option available to the parties to settle a dispute (Khan 1989). If conciliation was not reached, the dispute could be referred to binding arbitration by the minister of labor in the Industrial Court, after a joint application was submitted from the parties or on the minister's own initiative. The court, in making its award, was required to "have regard for the public interest, the financial implications, and the effect of the award on the country, the industry concerned and also to the probable effect on similar industries" (Ayadurai 1990). Furthermore, all collective bargaining agreements had to be "cognized" (certified) by the Industrial Court. The court had the power to refuse to cognize if the agreement contained provisions that were deemed not to be in the national interest.

Even under an import-substitution industrialization strategy, one could argue that the Malaysian system of industrial relations in the private sector was closely controlled by the state, the freedom of unions to organize and to bargain was severely restricted, and the industrial relations rules and regulations clearly reflected the state's efforts to contain industrial conflict in the interests of economic development. The prohibition on political strikes and the restrictions on the ability of peak bodies to carry out trade union functions also ensured that unions would not constitute a significant opposition to the government.

The nature of IR policy reflects a "controlled pluralism" during this period. Despite the considerable powers given to the state in industrial relations matters (Arudsothy and Littler 1993), the state's intervention, in terms of administrative practice, was relatively minimal.

\section{Industrial Relations Policy under EOI: Repression, Exclusion, and Cost Containment}

As we shall see, the shift in industrial relations policies arising from the adoption of EOI reflected the common strategic interests of the state 
and foreign investors. First, the dependence on low-cost, labor-intensive manufacturing for export forced the government to enact policies that kept costs low, so as to preserve Malaysia's competitive advantage in having cheap and disciplined labor and thereby continue to attract foreign investment. ${ }^{6}$ Naturally, the manufacturing and export sectors were the target of these policies. Second, the state increased its involvement in the industrial relations sphere to a considerable extent, moving from controlled pluralism to repression. The increase in repression reflected the state's need to increase the economic efficiency and productivity of state-owned enterprises and to sustain the EOI strategy. The specific mechanisms through which this shift was accomplished are described below.

Several rules and regulations directly affecting the competitive position of Malaysian exports were introduced. First, the minister of labor extended the tax and labor-exempt policies for Pioneer industries and industries in export processing zones (EPZs). Collective bargaining in this sector is circumscribed to the extent that the terms and conditions of employment may not be better than those defined under Part XII of the Employment Ordinance of 1955. Since there is no minimum wage legislation in Malaysia (except for certain classes of employees determined regionally), the Employment Act is concerned mainly with rates of pay for overtime, leave, and holidays. Second, the government has repeatedly refused to enact comprehensive minimum wage legislation, despite repeated demands by trade unions.

Third, in 1988, the definition of wages for the calculation of overtime was changed to reduce costs. Previously, wages for overtime included all allowances and bonuses; it now excludes them ( $\mathrm{Pi}^{\prime} \mathrm{i}$ and Kumaraguru 1989). In addition, the rate of overtime pay for working on days of rest was reduced from three to two times hourly pay, and pay for working on holidays was reduced from 4.5 to 3.5 times hourly pay. Although these reductions may appear reasonable, because of the shortage of unskilled and semiskilled labor in Malaysia (Arensman 1990), these reductions have significant cost implications. Union leaders argue that this change was the result of pressure from foreign electronics manufacturers located in Malaysia who were concerned about maintaining their competitive cost advantage (Grace 1990).

Fourth, the refusal of the government to enact equal pay for equal work is another example of its efforts to keep costs low to meet the demands of foreign companies (Grace 1990). Although females represent only 40 percent of the manufacturing work force, they account for more than 78.6 percent of the work force in the electronics industry. Arguably, this explains why the electronics industry has been exempted from the provisions of the Employment Act (1955), which forbade the employment of women between the hours of 10 P.M. and 5 A.M. Support for the exemption is evidenced by a 1988 amendment to the Employment Act, whereby the 
definition of days for maternity leave was changed to include holidays, rather than excluding them (Grace 1990).

Fifth, the government has been willing to grant exemptions from labor laws to foreign companies; for instance, in 1981, the government exempted the INTEL Corporation from the provisions of the Employment Act of 1955 and allowed INTEL to work its employees continuously for sixteen hours. More recently, the 1988 amendment to the Employment Act allows the director general of industrial relations to permit employers to work their employees for more hours than stipulated by the act, up to a maximum of forty-eight hours a week, giving considerably more flexibility to employers.

Sixth, the state continued its exclusionary policy with regard to the general banning of trade unions in the export sector. After intense pressure was brought to bear by the International Labour Organisation (ILO), the International Metal Workers' Federation, and leaders of the American labor movement (who unsuccessfully petitioned the U.S. government to revoke Malaysia's General System of Preferences [GSP] status for noncompliance with ILO conventions), the general ban was lifted in $1988 .^{7}$ A partial ban continues, however, in the form of a decision by the registrar that unions in the electronics sector can operate only on an "in-house" basis. This policy has circumscribed considerably the power of unions to organize. ${ }^{8} \mathrm{E}$. Grace (1990) finds that the ban was put into effect so as to appease U.S.based electronics manufacturers that threatened to move production outside the country.

Although in-house unions can now be organized in the electronics sector, recent outcomes in cases involving two factories that were subsidiaries of multinational companies, Harris Semiconductors (United States) and the Hitachi Group (Japan) (see Duthie 1990, Arensman 1990, and Barnard 1992 for details), make it abundantly clear that the right to organize exists in theory but not in practice. For example, after the workers in the Harris subsidiary won official recognition for their union in January 1990, the company shifted most of its operations and workers to a nonunion subsidiary. By April 1990, most of the workers had become nonunion, and Malaysia's high court ruled against the workers' petition that the shift was illegal. Currently, despite the existence of more than 140 companies in the electronics sector, only two electronics unions exist.

The outcomes at Harris and Hitachi are examples of how foreign corporations manipulate Malaysian trade union regulations to their advantage. The MTUC alleges, for example, that the Malaysian American Electronics Industry (MAEI), a trade group representing American employers in Malaysia, has pressured the Malaysian government into restricting workers' rights by threatening to close plants in Malaysia (Arensman 1990). The MTUC cites a letter written in 1986 to Malaysia's labor ministry by an official at General Instrument Corporation stating that "if 
there is a union of any kind, it is quite likely that GI corporate will sell this optoelectronic business, and it may mean closing an off-shore plant in Malaysia" (Arensman 1990:47). Although MAEI executives have denied the allegations, it is clear that Malaysian workers in the electronics industry face numerous obstacles to their right of freedom of association.

Although the evidence cited above supports the idea that foreign manufacturers demanded a policy of union suppression, it must also be remembered that the state has had a substantial interest in maintaining the low-cost advantage that Malaysian exports enjoyed. Every change in policy mentioned above reflects this objective.

\section{Increased Government Control and Involvement}

\section{in Industrial Relations}

In addition to enacting various "cost-containment measures" for the export sector, the government has systematically tightened labor rules and regulations in general. Here the changes reflect an increased "activism" on the part of the government, beginning with the onset of EOI in 1979-80 and continuing after EOI in 1988. Although I place more emphasis on EOI as the primary reason for the increase in government intervention, another significant factor has been the government's increased role as an employer, given its involvement in the NEP, ICA, and heavy industries program. One could argue that, given the poor performance of state-owned industries, the government's desire to promote economic efficiency has contributed to its increased involvement in regulating unions. Support for this argument can be seen in the changes in the government's policy consequent to the Malaysian Airlines (MAS) strike of 1979.

Following that strike, the Industrial Relations Act was amended, first, to give the minister of labor wide-ranging powers beyond the extensive ones already available to him with respect to industrial relations issues, including, most significantly, the power to declare any industry or service "essential." This implied that unions could be disallowed in essential services. Second, the minister was given the power to suspend a trade union for six months if he felt that it was acting against the national interest. Although the public sector MAS strike was the prime motivation for this change in legislation, it cannot be overlooked that, with increasing government intervention in industry as part of the NEP, ICA, and heavy industries policy, the government itself has become a significant shareholder in the private sector, with a direct interest in labor suppression beyond its purely regulatory role. "Essential," therefore, has broad connotations and can include airlines, food processing, electricals, road transportation, and any other industry deemed to be in the national interest. The following examples are illustrative of the government's increased intervention in the industrial relations sphere. 
Table 3.2. Union Recognition Claims in Malaysia, 1980-86

\begin{tabular}{|c|c|c|c|c|c|c|c|}
\hline & 1980 & 1981 & 1982 & 1983 & 1984 & 1985 & 1986 \\
\hline \multicolumn{8}{|c|}{ All Industries } \\
\hline Total claims & 125 & 149 & 119 & 112 & 169 & 224 & 224 \\
\hline Voluntary recognition & 54 & 74 & 59 & 38 & 51 & 3 & 7 \\
\hline \multicolumn{8}{|l|}{ Recognition accorded } \\
\hline by minister & 5 & 16 & 8 & 6 & 8 & 2 & 6 \\
\hline \multicolumn{8}{|l|}{ Recognition rejected } \\
\hline by minister & & 29 & 23 & 15 & 39 & 80 & 131 \\
\hline (Percent) & - & $(19.4)$ & $(19.3)$ & (13.3) & $(23.0)$ & $(35.7)$ & $(58.4)$ \\
\hline \multicolumn{8}{|c|}{ Manufacturing } \\
\hline Total claims & & 78 & 55 & 66 & 105 & 136 & 172 \\
\hline Voluntary recognition & & 44 & 26 & 25 & 30 & 26 & 20 \\
\hline \multicolumn{8}{|l|}{ Recognition accorded } \\
\hline by minister & & 4 & 5 & 5 & 5 & 1 & 2 \\
\hline \multicolumn{8}{|l|}{ Recognition rejected } \\
\hline by minister & & 12 & 13 & 7 & 26 & 62 & 98 \\
\hline (Percent) & & $(15.3)$ & $(23.6)$ & $(10.6)$ & $(16.7)$ & $(45.5)$ & $(56.7)$ \\
\hline \multirow{3}{*}{\multicolumn{8}{|c|}{$\begin{array}{l}\text { Rejections in } \\
\text { manufacturing as } \\
\text { percentage of total }\end{array}$}} \\
\hline & & & & & & & \\
\hline & & & & & & & \\
\hline rejections & & 41.3 & 56.5 & 46.6 & 66.6 & 77.5 & 74.8 \\
\hline
\end{tabular}

Sources: Department of Industrial Reiations. Kuala Lumpur, and Pehie, Mansour, and Chen 1988.

Trade Union Recognition Claims. Consistent with the more activist stance of the government, the minister of labor's involvement in union recognition claims has been increasing. As table 3.2 indicates, his rate of rejection of claims for recognition has increased, and the proportion of rejections to total rejections in manufacturing has increased substantially. Under normal circumstances, once a union is registered after meeting the stringent requirements of the registrar of trade unions, it requests recognition by the employer. If the employer does not voluntarily recognize the union (and invariably the employer does not, as table 3.2 shows), the claim is sent to the director general of industrial relations for investigation. The minister of labor makes a final and binding decision on recognition. At least half the recognition claims have been in the low-cost, labor-intensive manufacturing areas of textiles and light electricals. This is where the greatest number of recognition claims have been rejected by the minister, al though data are available only until 1986.

Government Intervention in Dispute Settlements. The activist stance of the government is reflected in dispute settlements in two ways. First, the labor minister has been far more willing to refer disputes on his own initiative for binding arbitration to the Industrial Court. This effectively curtails the operation of free collective bargaining. This practice has increased 
Table 3.3. Number of Dispute Settlements in Malaysia in Which Labor Minister Was Involved, 1981-86

\begin{tabular}{|c|c|c|c|c|c|c|}
\hline & 1981 & 1982 & 1983 & 1984 & 1985 & 1986 \\
\hline No. of disputes & 498 & 606 & 836 & 757 & 827 & 956 \\
\hline \multicolumn{7}{|l|}{ No. settled by } \\
\hline conciliation & 398. & 538 & 741 & 602 & 666 & 675 \\
\hline \multicolumn{7}{|l|}{$\begin{array}{l}\text { No. referred to } \\
\text { industrial court }\end{array}$} \\
\hline (total) & 89 & 60 & 54 & 107 & 113 & 158 \\
\hline \multicolumn{7}{|l|}{$\begin{array}{l}\text { No. referred by joint } \\
\text { application of the }\end{array}$} \\
\hline parties & 35 & 32 & 15 & 20 & 34 & 44 \\
\hline $\begin{array}{l}\text { No. referred by } \\
\text { minister on own }\end{array}$ & & & & & & \\
\hline initiative & 54 & 28 & 39 & 87 & 79 & 114 \\
\hline No. settled by minister & 11 & 8 & 39 & 48 & 48 & 121 \\
\hline \multicolumn{7}{|l|}{ Percentage settled by } \\
\hline minister & 2 & 1 & 4.6 & 6.34 & 5.80 & 12.68 \\
\hline
\end{tabular}

Source: Compiled by the author from Bot 1988.

dramatically and at a much greater rate than the rate of industrial disputes. Second, as table 3.3 shows, in many cases, the minister has used the power of his office to effectuate settlements, in some cases by convincing one party to modify its demands, in the interest of keeping the peace. Since manufacturing accounts for 41 percent of all disputes (see table 3.6), it follows that the minister becomes involved in dispute settlements much more in this sector.

Amendments to Collective Agreements. Malaysian labor law requires that once an agreement is reached, it must be cognized - that is, submitted to the Industrial Court - which then provides legal status to the agreement by converting it to an award of the court. The Industrial Court has the power either to reject a collective bargaining agreement or to suggest modifications before cognizance, if the court determines that provisions of the award are against the national interest. This provision limits goodfaith bargaining, since employers can agree to "excessive" wage demands made by unions, knowing that "high wage costs" are likely to be deemed as against the national interest and modified by the court.

Although this system existed under ISI, as noted earlier, since EOI, as table 3.4 shows, there has been a steady increase in the number of agreements that have been sent back to the parties for amendment before cognizance was granted. In 1985, more than 50 percent of the agreements were accepted only after amendments were added. Clearly, the Industrial Court has been acting under the directions of the labor ministry. As Arudsothy (1990) suggests, the Industrial Court has been operated virtually as an instrumentality of the Ministry of Labour. Any semblance of 
Table 3.4. Number of Collective Agreements in Malaysia Accepted by Industrial Court with and without Amendments, 1978-85

\begin{tabular}{lccc}
\hline Year & $\begin{array}{c}\text { Total agreements } \\
\text { deposited }\end{array}$ & $\begin{array}{c}\text { No. accepted } \\
\text { without } \\
\text { amendments }\end{array}$ & $\begin{array}{c}\text { No. accepted } \\
\text { with amendments }\end{array}$ \\
\hline 1978 & 186 & 186 & 0 \\
1979 & 204 & 204 & 0 \\
1980 & 207 & 114 & $93(44 \%)$ \\
1981 & 262 & 221 & $41(15.5 \%)$ \\
1982 & 266 & 140 & $125(46.4 \%)$ \\
1983 & 268 & 123 & $136(50.7 \%)$ \\
1984 & 234 & 110 & $117(50 \%)$ \\
1985 & 330 & 145 & $185(56 \%)$ \\
\hline
\end{tabular}

Source: Sivagnanam 1988.

Table 3.5. In-bouse Unions in Malaysia, 1984-88

\begin{tabular}{|c|c|c|c|c|c|}
\hline & 1984 & 1985 & 1986 & 1987 & 1988 \\
\hline Total & 177 & 189 & 199 & 210 & 224 \\
\hline Percentage of total unions & 49.3 & 51.2 & 52.5 & 51.3 & 54.5 \\
\hline $\begin{array}{l}\text { Percentage of private } \\
\text { sector unions }\end{array}$ & 28.2 & 32.5 & 36.1 & 36.7 & 38.2 \\
\hline $\begin{array}{l}\text { Percentage of statutory } \\
\text { authority unions }\end{array}$ & 94.8 & 95.1 & 95.1 & 95.1 & 96.6 \\
\hline $\begin{array}{l}\text { Percentage of government } \\
\text { service unions }\end{array}$ & 45.8 & 47.2 & 47.6 & 47.2 & 46.7 \\
\hline
\end{tabular}

Source: Arudsothy and Littler 1993.

independence was further removed in 1986, when the government decided that the appointment of officers of the court would be left largely to the discretion of the minister.

Enterprise or "In-House" Unions. Under the Trade Unions Ordinance of 1959, unions could be organized on an occupation-within-industry basis and could affiliate themselves with national unions but could not have national unions represent them for trade union purposes. Although this policy was designed to keep unions small and responsive to the particular conditions of their industries, it was also a system by which the labor movement could be kept fragmented in ways that would threaten the government politically (Arudsothy and Littler 1993).

Under Dr. Mahathir Mohammed's "Look East" policy, the successful example of Japanese enterprise unions was introduced to Malaysian legislation, although in-house unions were in existence even before by means of the registrar's decisions. ${ }^{9}$ Table 3.5 shows the rapid growth in the number of enterprise unions since the 1980s. 
In 1985-86, out of twenty-eight new unions registered, twenty-seven were enterprise unions. In theory, enterprise unions organized on Japanese lines produce more integrative labor-management relations since the goals of the enterprise and the unions coalesce. It must be remembered, however, that enterprise unions are only one feature of various interrelated polices in Japan that make the industrial relations system successful. For instance, long-term employment contracts, seniority-based pay systems, firm-specific training systems, and considerable labor-management consultation reinforce the enterprise union system. In Malaysia, the concept of enterprise unions alone is unlikely to result in the kind of stable and flexible labor-management relations that the Japanese have and the Malaysian government seems to want. The other ingredients, notably the acceptance of unions as a partner in the business, are noticeably absent.

There are other contradictions in promoting enterprise unions. For instance, if an enterprise union is to be successful, all employees in the enterprise must become members. Under Malaysian law, however, various classes of employees, including supervisors, secretaries, and security personnel, are not allowed to become members of a union. Further, there are considerable restrictions on unions concerning the subject matter of bargaining, and little or no participation in workplace decision making exists. Given these conditions, the criticism that the legislation requiring enterprise unions was enacted to keep the labor movement fragmented is certainly plausible.

Policy on Labor Federations. The latter criticism is supported by the government's unwillingness to consider forming one major labor federation. Attempts in 1985 to unify the two major federations, the Malaysian Trade Union Congress and the Congress of Unions of Employees in the Public and Civil Services (Malaysia) (CUEPACS), failed since the registrar of trade unions requested numerous changes in the proposed constitution that the unions felt were impossible. Although this reflects the government's desire to discourage the formation of a national union federation, recent restrictions on trade union rights in the public sector have forced some public sector unions to affiliate with the MTUC. Increased disillusionment with its traditional leadership has prompted the promotion of a rival national federation by the National Union of Newspaper Workers, which is still unrecognized by the government. The government's determination to keep the labor movement fragmented is also evidenced by its "behind-the-scenes" support of a rival labor federation-the Malaysian Labour Organization (MLO)-sponsored by the Bank Employees' Union, which currently has fifteen affiliated unions with 142,000 members (Arudsothy and Littler 1993).

The general tightening of labor relations laws and the suppression of unionization and collective bargaining rights noted in the private sector have had some spillover effects in the public sector. Arudsothy (1990) 
suggests that all sections of the public sector have progressively been excluded from the provisions of parts of industrial relations legislation. The right to strike in the public sector is largely illusionary, given the inapplicability of Parts II-VI of the Industrial Relations Act and the elaborate rules that effectively circumscribe the right to strike. There has, in fact, been a shift to a more unitary and paternalistic system of industrial relations in the public sector (Arudsothy and Litrler 1993).

In sum, as these examples demonstrate, the state's role as an employer and its dependence on foreign investment for its manufacturing base, particularly in the electronics industry, has created a labor relations system that is repressive and dominated by the government. The shift from ISI to EOI was the primary catalyst for the tightening of labor relations policies. The specific cost-containment policies were determined by the government in response to pressure from foreign companies on which it was so dependent. The involvement of the government in industrialization also appears to have been important. The federal government is now involved in industrial relations in many different ways: as a sponsor of IR legislation; as an administrator of IR legislation; as a third party in dispute settlements; as an employer in the public sector; and as a stakeholder in various private corporations (Ayadurai 1990).

\section{Consequences of Industrial Relations Policies}

The changes in state industrial relations policy in Malaysia have led to several important outcomes. These are discussed below. It is worth noting that the impact of these changes tends to be reflected primarily in the industrial sector. Other sectors of the economy, such as the plantation sector, where there has been a longer history of bargaining and there have been well-entrenched unions, remain relatively unaffected. Nevertheless, in the context of a rapidly industrializing economy, it is the manufacturing sector that sets industrial relations trends; hence, the focus on this sector.

\section{Structural and Institutional Consequences}

State labor policies have left Malaysian unions weak and fragmented at the national level. Union density, defined as the percentage of the total work force that is unionized, declined from 11.2 percent in 1985 to about 9.4 percent in 1990 . Measured as a percentage of the nonagricultural work force, union density is about 17 percent. Much of this decline can be attributed to state policy and employer opposition (Arudsothy and Littler 1993). In the manufacturing sector, the largest and fastest-growing sector of the economy in terms of employment and contribution to GDP, union density is less than 11 percent. In the plantation sector, where there has 
been relatively less government intervention, the figure is 46 percent (Arudsothy 1991).

Unions remain fragmented and small, resulting in organizational and financial weaknesses that limit their ability to organize effectively and to represent their members (Arudsothy and Littler 1993). Although central union federations exist, such as the MTUC, CUEPACS, and the government-supported MLO, their effectiveness is limited, given that they cannot involve themselves in collective bargaining or unionlike activities since they are incorporated as societies. Moreover, there is little unity among these organizations, thus limiting their ability to mobilize the work force. The wide-ranging powers given to the registrar of trade unions and to the labor minister further serve to contain union action.

Bargaining in the private sector tends to be decentralized, so that there are a variety of different bargaining structures (Arudsothy and Littler 1993) and little evidence of pattern bargaining. By and large, bargaining power rests with the employers, given the limitations on the ability of unions to strike. Collective bargaining agreements are in force for a legislatively mandated period of three years, thus limiting the ability of firms to respond quickly to changes in the economic environment (Ayadurai 1990). The wage system also exhibits a number of institutional rigidities, such as predetermined automatic annual adjustments and nonadjustable contractual bonuses, and wages are linked to seniority (Salih 1988).

Although dispute settlement is effective in terms of the success of conciliation, the limitation on the subjects that can be raised as disputes (by virtue of the restricted scope of bargaining) makes the effectiveness of conciliation less certain. The number of strikes in Malaysia has been steadily declining, as can be seen from table 3.6.

Although administrative procedures limit the freedom to strike, this does not mean that there is little conflict in the system. Rather, the limitations on strikes tend to increase the dependence on third-party dispute resolution, having a so-called narcotic effect. The number of strikes has declined, but the number of disputes has been increasing steadily, indicating substantial conflict in the system. Relevant data are provided in tables 3.6 and 3.7 .

The rise in disputes has been mostly in manufacturing. This sector accounted for the majority of disputes- 41 percent - in 1986. The correlation between the number of strikes and the number of disputes is negative at $.45(\mathrm{p}<.05)$, suggesting that the restrictions on striking do result in increased conflict through more disputes and thereby control the level of unionism. Although unionization increased by only 1 or 2 percentage points over the period 1981-86, the number of disputes doubled. The increase in the number of disputes, therefore, is evidence of the weakness of Malaysian unions and the consequent reliance on third-party dispute resolution mechanisms. 
Table 3.6. Number of Unions, Strikes, and Disputes in Malaysia, 1981-89

\begin{tabular}{lccc}
\hline & Unions & Disputes & Strikes \\
\hline 1981 & - & 498 & 24 \\
1982 & 383 & 606 & 26 \\
1983 & 386 & 834 & 24 \\
1984 & 386 & 757 & 17 \\
1985 & 392 & 827 & 22 \\
1986 & 401 & 1123 & 23 \\
1987 & 409 & 100.1 & 20 \\
1988 & 398 & 989 & 9 \\
1989 & 322 & - & 7 \\
\hline
\end{tabular}

Table 3.7. Distribution of Disputes in Malaysia, by Industry, 1983-86

\begin{tabular}{lcccc}
\hline \multicolumn{1}{c}{ Industry } & 1983 & 1984 & 1985 & 1986 \\
\hline Manufacturing & 296 & 270 & 388 & 468 \\
$\quad$ Percent) & $(35.8)$ & $(37.3)$ & $(45.0)$ & $(41.67)$ \\
Plantation & 276 & 212 & 191 & 232 \\
Transport & 128 & 127 & 147 & 218 \\
Services & 65 & 66 & 65 & 104 \\
Commerce & 36 & 26 & 40 & 43 \\
Other & 25 & 21 & 31 & 58 \\
\hline
\end{tabular}

Limitations on the subject matter of bargaining, state intervention to prevent or contain strikes, and the weakness of trade unions result in an industrial relations system in which the unions are extremely dependent on third-party intervention. Such involvement by the government inhibits the development of a pluralistic system characterized by free collective bargaining. It can be argued that the system does not create the climate under which unions and managements can develop collaborative relationships, based on their bargaining strength, necessary for mutual problem solving.

\section{Industrial Relations Practices of Firms}

The antiunion stance of the Malaysian government complements the antiunion stance of Malaysian employers. Employer opposition to unions is widespread. P. Arudsothy and C. Littler (1993) note that union busting and other antiunion activities increased during the 1980 s relative to the 1970s. Indigenous companies appear far more inclined to be antiunion than foreign-owned concerns, although union avoidance appears to be the dominant strategy in export-oriented manufacturing and electronics.

Despite the government's announcement that unions could be formed in 
the electronics industry, only one enterprise union has been established. E. Grace (1990) suggests three reasons for this phenomenon. The first reason is that the workers view enterprise unions with skepticism and mistrust; the second is that they fear employer reprisals if they join a union; and the third is that it has become clear to workers that examples of unionization drives in other companies result in increases in wages and benefits in their own (i.e., a union substitution effect).

Employers clearly use both union suppression and union substitution strategies in dealing with workers. Motorola, for example, increased its workers' pay and benefits one month after the government's announcement that unions could be formed in the electronics industry (Grace 1990). The owner of one U.S. electronics factory offered a box of Kentucky Fried Chicken to any worker willing to disclose the name of persons signing a union membership application. Another U.S. corporation invited a Muslim religious instructor to speak during working hours about why it was against the Islamic faith for women to become members of a union.

Motorola, Matsushita, and many other companies have threatened to move operations to Thailand and China if a union was formed. Workers in these companies who have exhibited pro-union sentiments have routinely been transferred to other plants and intimidated.

In June 1990, Hitachi's Malaysian subsidiary fired 1,003 striking workers after they walked out in protest of the government's refusal to allow their in-house union to be represented by a national electrical workers union. Although most of the workers were hired back after they apologized, workers who were considered activists were not reinstated. Although Hitachi clearly was within the law in this case, its unwillingness to reinstate the activists suggests the company's antagonism toward unions, a view shared by many American and Japanese employers. Clearly, although unions are weak as a result of government policy, they are further weakened by employer policies and by the interaction of government and employer policies.

\section{Evidence of New Industrial Relations and Human Resource Practices}

Despite the intense avoidance of unions in Malaysia, leaders of plantlevel industrial relations, particularly in the modern bellwether electronics sector, are gradually moving toward practices followed in similar industries in more advanced countries, such as Germany, Japan, and the United States. Changes in the production processes in the electronics industry, for example, have brought about changes in industrial relations practices. In the early $1980 \mathrm{~s}$, by and large, the production system was driven by "Fordist" methods, characterized by assembly-line systems in which workers did highly specialized and repetitive tasks requiring minimal skill and 
training. Wages above the daily base rate were based on a variety of piece rates and production incentive systems (Rasiah 1988; Grace 1990).

Given the effect of two recessions, however, there has been considerable restructuring of the production processes in an effort to increase efficiency. The industry is being increasingly automated, and new manufacturing systems, such as just in time, total quality management, and materials requisition planning (MRP), have been introduced in many plants. These new systems have brought with them new methods of training and remuneration systems. Increasingly, wages are tied to learning new skills. R. Rasiah (1988) notes that in many companies a production worker needs to know at least three processes to become a super-operator with a salary of almost M\$750 a month (approximately U.S.\$300). The team concept in production has been introduced in many U.S.-owned plants, giving workers more and more input into the manufacturing process and in many cases resulting in more efficient production and lower employee turnover. Texas Instruments, for example, has had exemplary success with the introduction of self-managed teams for production and quality control (Arensman 1991). Turnover rates have declined to 3 percent, and 85 percent of the employees have been in their jobs for more than five years. This contrasts with the electronics industry more generally, where labor turnover reached about 35 percent in 1985-86. There is still no job security, however, even for regular production staff.

In other parts of the economy, there are isolated examples of the emergence of new industrial relations practices, based on the acceptance of trade unions and employee involvement. For instance, since the 1979 strike at Malaysian Airlines, industrial relations have become stable and unions have become somewhat involved in decision making. Joint consultative committees, composed of union-management representatives, decide on grievances and quality issues, and turnover has declined to less than 3 percent. In a manufacturing organization (Seng and Hashim 1987), management meets once a month with the area union committee to resolve issues, and the managing director meets with union representatives on a regular basis. Employee involvement has been increasing since the introduction of self-managed teams for quality control and production improvement, and employee suggestions have increased dramatically, to an average of 17.2 per employee in 1988. The banking sector has also undergone changes, including increased employee participation, and an "interrelations" committee, composed of union and management representatives, meets periodically to resolve industrial relations issues and to plan production (Arul, Saidin, and Abu 1987).

There are several motivations for these new practices. In the state-owned enterprises, there is a gradual realization that productivity enhancements require the active participation of the workers. In other companies, the shift to more employee participation may be driven by competition, 
changes in technology, and the need for increased flexibility. At the same time, it is also possible that this shift to the institution of more human resource management techniques reflects a desire for more sophisticated forms of labor control.

It is difficult to conclude that these changes represent a clear trend, however. To reach such a conclusion would require a comprehensive survey of industrial relations practices. A key question here is the extent to which these new forms of human resource management will be successful in the absence of other policies that appear essential to the creation of stable and flexible industrial relations systems, such as increased job security, increased training to prepare workers to participate more actively in decision making, and more cooperative labor-management relations (Katz, Kuruvilla, and Turner forthcoming).

\section{Future Issues}

Assuming that the process of export-oriented industrialization follows the standard pattern in the region (i.e., simple EOI to more advanced EOI) (Bjorkman, Lauridsen, and Marcussen 1988), the current labor policy articulated by the Malaysian government may result in some future dysfunction. First, Malaysia's competitive advantage, based on its low labor costs, is likely to be eroded given the competition from the Philippines, Thailand, China, and Vietnam. A key issue is whether Malaysia can make the investments necessary to increase its workers' skills through education, training, and labor market policies and thereby upgrade its industries and attract more high-technology investment.

Second, the rapid technological changes occurring in the electronics sector require changes in the method of labor utilization. Rapid technological change to more high-cost, high-skill, capital-intensive methods of production may induce foreign investors to relocate to their own "highskill/high-cost" countries or to Malaysia's competitors (e.g., Singapore) unless Malaysia can provide the kind of work force the foreign investors need.

These changes have several implications for industrial relations practice. First, they require the creation of a well-educated and highly trained work force that is capable of participating in production decisions characteristic of the new post-Fordist production methods. Second, to develop such a work force requires personnel policies, such as increased job security, training, wage systems, joint problem solving, and cooperative labormanagement relationships, that enhance participation and knowledge acquisition, Third, these changes are not possible unless state and employer labor policy become less repressive and more collaborative. More fundamental changes, therefore, appear necessary.

Current evidence suggests that such changes are indeed occurring 
(Kuruvilla 1994). Already, investment incentives have been restructured to attract higher technology-based investments, and the Malaysian education system has been deregulated, resulting in a mushrooming of private colleges with exchange arrangements with universities in Australia and Canada. This should lead to an increase in the supply of qualified workers for higher-technology industries. In addition, the government enacted the Human Resources Development Act of 1992, which instituted the Skills Development Fund. The law forces larger enterprises to pay a certain percentage of their payroll costs into the fund, to which the government contributes a matching sum. The funds are used to subsidize the training costs of all firms that apply for funds. Immigration policies have also been restructured to permit the import of both skilled and unskilled guest workers to meet the demands of industry.

Clearly, the focus of government policy has shifted from cost containment and involvement toward skills development. In addition, in the heavy industries sector, there is an increased focus on labor-management cooperation. Policies oriented toward skills development at the national level are complemented by employer approaches emphasizing increased worker involvement. The movement in the electronics industry is toward increasingly positive human resource management in a nonunion environment.

\section{Conclusion}

It would appear that the ISI strategy was associated with an industrial relations policy that was, in some sense, pluralistic. With the shift to EOI, however, the government labor policy essentially became repressive and exclusionary. The motivation for this repressive policy stemmed from the demands of the EOI strategy (for a low-cost, labor-intensive strategy) to attract foreign investment. There is some evidence that foreign manufacturers did exert some pressure on the Malaysian government to contain costs. The mechanisms by which repressive state policies were enacted included various changes in the industrial relations rules and increased government involvement in the industrial relations sphere.

This chapter has a number of limitations that deserve mention. First, it is implicitly assumed that the restrictions on trade union rights in Malaysia favor employers in all sectors in the same way. This may not be true, particularly with respect to the plantation sector.

Second, this chapter did not address variations in the abilities and strategies trade unions have used to counter and mobilize against government and employer policies. The focus has been on the export-oriented manufacturing sector, where unions are exceptionally weak, because this 
focus helps illustrate the underlying theoretical argument that is being proposed.

Third, it would be useful to disentangle further employers' motivations to change their industrial relations practices. On the one hand, employers following an antiunion strategy may be motivated entirely by cost considerations. On the other hand, the recent move toward cooperation and worker involvement may represent a movement toward more sophisticated forms of worker control through "corporatist" practices. It is also possible that the movement toward cooperation may be due to changes in production technologies that require greater levels of worker involvement.

From a comparative industrial relations research standpoint, this chapter raises several questions regarding the explanatory role of industrialization policies in affecting industrial relations policy. Are certain types of industrialization strategies associated with certain types of IR systems? Are there variations within an industrialization strategy that have implications for different IR policies? What is clear from the evidence is that a shift in industrialization strategy has an effect on an industrial relations system. (This conclusion appears supported by more recent comparative investigations in Singapore and the Philippines [Kuruvilla 1994, 1995]). Future researchers may wish to consider these issues in more detail.

Implicit in this case is the notion that the shift from one industrial strategy to another represents a discrete moment in the transition of economies and industrial relations systems. History shows that there are key moments of transition in industrial relations systems, after which they get set and are hard to modify. Often these key moments are a result of legislative changes (e.g., the National Labor Relations Act in the United States) or other economic junctures (e.g., postwar reconstruction in Germany and Japan) or historical factors (e.g., independence movements in the Third World). Recent policy prescriptions forcing Third World countries to liberalize their economies to integrate into the world market (e.g., India) require changes in industrialization strategies that provide yet another moment in transition for industrial relations systems. For those interested in the transformation of industrial relations systems in Third World countries, focusing on the shifts in industrialization strategy may be a particularly useful starting point for study. 